\title{
The Effectiveness of Learning Experience Approach to Improve Reading Ability of Dyslexic Children
}

\author{
Siti Latifah ${ }^{1}$, Sunardi $^{2}$, and Asrowi ${ }^{3}$ \\ \{sitilatifah@student.uns.ac.id ${ }^{1}$, nardi_ip@uns.ac.id ${ }^{2}$, asrowi@yahoo.com ${ }^{3}$ \} \\ ${ }^{1,2,3}$ Special Education Program, Faculty of Postgraduate, Universitas Sebelas Maret Surakarta, \\ Indonesia
}

\begin{abstract}
Dyslexia is a specific learning disability derived from neurological. This is characterized by the difficulty of recognizing an accurate word and poor spelling and decoding ability. This research aims at determining the effectiveness of the language experience approach to improve reading skills of dyslexic students. This research is an experimental research in the form of Single Subject Research which applies ABA design. The subjects of the research are two second grade dyslexic students. The data were collected using the test works technique and analysed using descriptive statistics technique. The result of the data analysis shows that the language experience approach is proven to increase the average score of the two subjects. In the baseline 1, the average score obtained by YD was 34.6. After the intervention was given, YD obtained 43.9. In the measurement in baseline 2, YD final score increased to 51.7. Meanwhile, the average score obtained by BT in the baseline 1 was 36.3.After the intervention was given, BT obtained 42.5. Finally, in the measurement in baseline 2, BT final score increased to 49.7. In conclusion, the use of the language experience approach is effective at improving reading ability of second grade dyslexic students.
\end{abstract}

Keywords: learning experience approach, reading ability, dyslexia

\section{INTRODUCTION}

In real life, not every child experienced a normal language development. Children with dyslexia will face difficulties in acquainting languages compares to normal children in general. In 1878, a German physician named Rudolf Berlin developed the term of dyslexia to describe the big hardship in interpreting written or printed symbols [7]. Dyslexic children according to Curtin, Manis, and Siedenberg are specific functional failures to read properly that is happened at children who supposedly develop normally [14]. Compared to children of their age, dyslexic children are lacking of vocabulary, stammering while reading, experiencing a continuing problem to describe something, they do not understand what they are reading, having difficulties in reading comprehension caused by the problem of understanding the word order, they are always flipping the words, their reading ability does not match their visible intelligence and vocabulary, they often substitute visually similar words (for instance "this" for "that"), their reading level is low, unorganized words while reading, they continue to 
rely on pointing fingers while reading (for older students), their lips keep moving while reading(for older students)[19].

One of the factors that inhibit someone's reading ability to be functioned normally according to Hoien and Lundberg is phonological. A person with dyslexia usually indicates difficulty in performing phonological decoding [1][2][4].In line with Hoien and Lundberg, the International Dyslexia Association [5][17] defines dyslexia as a specific learning disability derived from neurological. This is characterized by the difficulty of recognizing an accurate word and poor spelling and decoding ability [3]. This difficulty is usually caused by an unexpected deficiency in the phonological language component that can be associated with the other cognitive abilities and an effective classroom instruction.

Tampubolon states that reading is one of the essential language skills, and is the part or component of written communication [6]. Meanwhile, Bond argues that reading is the introduction of symbols of writing language that can be used as the stimulus to help the process of remembering what is being read. It is intended to create an understanding through experiences [9].

There are some aspects during the process of reading. Broughton, et al [18] states that there are two aspects of reading process including: (1) Mechanical skill that can be considered as the lower order. This aspect includes: the introduction of letters; the introduction of linguistic elements (phonemes / graphemes, words, phrases, clause patterns, sentences and others); the introduction of spelling and sound pattern correlation / correspondence (the ability to bark at print); and the reading speed to a slower level. (2) Comprehension skill that is considered as the higher order. This aspect includes: understanding a simple definition (lexical, grammatical, and rhetorical); understanding the meaning (author's intent and purpose, cultural relevance / circumstance, and readers' reaction); evaluating or researching (content, form); and a flexible reading speed, which can be easily adjusted based on particular circumstances.

During reading process, there is a purpose that is going to be received. Stahl [15] states that the purposes of reading for the students are: to recognize the word automatically, to understand the text, and to motivate them to read and appreciate the text.

Further, [16] explains that the process of learning to read is divided into 4 phases, there are: (1) pre-alphabetic phase reader, this phase shows the reading activity but without knowing the letters; (2) a partial alphabetical reader, this phase allows the reader in recognizing symbols such as letters or numbers in the half of the text; (3) full alphabetic phase readers, this phase allows the readers in recognizing new words by looking at any combination of letters, numbers, or other punctuation; and (4) consolidation phase readers that allows the readers in understanding the content of the text.

To support the reading process, there are a number of strategies that can be used. Polloway and Patton states that generally, the reading approach can be divided into two types: development and remedial. The development approach emphasizes the daily experiences. The remedial approach is undertaken to help the students who have difficulty in learning to read [12].

Language experience approach is one of the learning strategies that apply a basal series. However, this approach of strategy cannot be used with the other strategy. The language experience approach strategy encourages students to express their thoughts and experiences verbally, and then the students write those experiences by themselves. This story is then being re-read by the other students as the progressive of this program. This approach can be used to develop student's word recognition skills. Phonetic and structural analysis skills are given during the observation of students' readiness to learn the lesson [12]. 
[8] further states that the Language Experience Approach requires following steps: 1) providing meaningful experiences or stimuli; 2) write the story using their own languages; 3 ) read the story they just wrote; 4) ask the students to find the words contained in the story, count the number of words, focus on particular words, and write the words; 5) develop basic skills. Meanwhile, according to [11] the Language Experience Approach procedures are: preparing dictation, providing dictation, reading stories, implementing, and developing basic skills.

Based on the research conducted by [13] it can be seen that the implementation of Language Experience Approach in the process of learning can successfully improve the students' motivation in learning and reading. [10] on her research also states that Language Experience Approach can effectively improve the ability of reading.

The purposes of this research are: 1. to find out whether Language Experience Approach can affect the reading ability of the second grade elementary school dyslexia students; 2 . to find out the effectiveness of Language Experience Approach for the improvement of reading ability of the second grade elementary school dyslexia students.

\section{METHOD}

This research is applied quantitative approach using Single Subject Experiment Design. This research applied A-B-A design. According to [24] A-B-A design is one of the developments of A-B basic design; A-B-A design has shown a causal relationship between the dependent variable and independent variable. The subjects in this research are two second grade dyslexia students of primary school in Surakarta. The data of this research were collected using the test works technique. The reading text is used to measure students' reading abilities at baseline 1 (A1), intervention (B), and baseline 2 (A2). The data were analyzed to determine the effect of the Language Experience Approach on the reading process of the subject. The data were analyzed using analysis under condition technique. Analysis under conditions is an analysis of data changes that is used in a particular condition. This research analyzes the length of the condition, the tendency of direction, the tendency of data stability, the data trace, the level of stability and range and the level change.

\section{RESULT AND DISCUSSION}

\subsection{Baseline 1 description (subjects' initial abilitybefore intervention is given)}

The measurements at the baseline 1 are undertaken with three times meeting, to determine the initial ability of the subjects' reading ability by providing the reading text. The scores obtained by both subjects in the baseline 1 tend to be low. This can be possibly caused by the difficulties in various aspects such as the distance of the sight while reading the text is too close, continuous errors, sound, fluency, and understanding. Based on the problems at baseline 1, the researcher gave the intervention using the Language Experience Approach. The intervention was conducted eight times using a number of media learning such as images, video and the environment around the subjects. The learning process applying a Language Experience Approach can improve subjects' reading skills and increase their motivation in learning. The subjects were more motivated to learn reading by involving the daily activities of the subjects.

\subsection{Intervention description (during intervention process)}

At the first intervention session, the subjects were given a number of questions related to drawing/video observed. The researcher then wrote the words that came from the subjects 
according to what the objects saw through the. For instance, the researcher played the video about soccer. At the second intervention activity, the researcher wrote the words that were being said by the subject based on what was being seen through the video or activities that have been held directly by the objects related to playing ball. Furthermore, at the third intervention activity, the researcher wrote the words that were being said by the subject based on what was being seen through the video or activities that have been held directly by the objects related to playing ball. At the fourth intervention activity, the researcher wrote the words that were being said by the subject based on what was being seen through the video or activities that have been held directly by the objects related to playing ball. Moreover, at the fifth intervention activity, the subjects were allowed to observe the media in the form of picture/videos about daily activities. Further, the subjects were given a number of questions related to the picture/video. The researcher wrote the words that came from the objects minds, and then the subjects read the text that was written by the researchers. The sixth intervention session applies similar method to the previous intervention session. The subjects were allowed to observe the media in the form of picture/videos about daily activities. Further, the subjects were given a number of questions related to the picture/video. The researcher wrote the words that were being said by the subject based on what was being seen through the video or activities that have been held directly by the objects related to their daily activities. The subjects then read the text that was written by the researcher. Moreover, the seventh intervention session applies similar method to the previous intervention session. The subjects were allowed to observe the media in the form of picture/videos about daily activities. Further, the subjects were given a number of questions related to the picture/video. The researcher wrote the words that were being said by the subject based on what was being seen through the video or activities that have been held directly by the objects related to their daily activities. The subjects then read the text that was written by the researcher. The eight intervention session applies similar method to the previous intervention session. The subjects were allowed to observe the media in the form of picture/videos about daily activities. Further, the subjects were given a number of questions related to the picture/video. The researcher wrote the words that were being said by the subject based on what was being seen through the video or activities that have been held directly by the objects related to their daily activities. The subjects then read the text that was written by the researcher.

\subsection{Baseline 2 description (the process afterintervention is given)}

The baseline 2 measurement was conducted three times after the intervention session. The text used to measure the reading ability of the subject named "BT" was started with the easiest text first. In the first sessions of the baseline 2 measurement, the subject was given the text entitled "main bola". In the second sessions of the baseline 2 measurement, the subject was given the text entitled "tenis meja". However, in the third sessions of the baseline 2 measurement, the subject was given the text entitled "kegiatanku"

Below, is the table of comparison of the reading ability scores on the phase of baseline 1 , intervention, and baseline 2 .

Table 1. The Scores Comparison of Reading Ability from Each Subject

\begin{tabular}{|c|c|c|c|c|c|c|}
\hline Subject & \multicolumn{3}{|c|}{ YD } & \multicolumn{3}{|c|}{ BT } \\
\hline $\begin{array}{l}\text { Phase } \\
\text { Session }\end{array}$ & A1 & B & A2 & A1 & B & A2 \\
\hline 1 & 34 & 39 & 51 & 36 & 37 & 49 \\
\hline 2 & 34 & 41 & 52 & 36 & 38 & 49 \\
\hline
\end{tabular}




\begin{tabular}{|c|c|c|c|c|c|c|}
\hline 3 & 36 & 42 & 52 & 37 & 41 & 51 \\
\hline 4 & & 42 & & & 41 & \\
\hline 5 & & 45 & & & 43 & \\
\hline 6 & & 46 & & & 45 & \\
\hline 7 & & 48 & & & 47 & \\
\hline 8 & & 48 & & & 48 & \\
\hline Average & 34,6 & 43,9 & 51,7 & 36,3 & 42,5 & 49,7 \\
\hline
\end{tabular}

Based on the table, it can be seen that there is the difference between baseline 1 phase, the intervention, and baseline 2 phase related to the obtained scores. Further, the table clearly shows the improvement of reading ability on the subjects. However, this research involved more than one subject. Thus, the data analysis and was presented individually based on the subjects' characteristics. The reason of choosing more than one subjects is because each treatment that was given by the researchers can be used for comparison between the two subjects. The following graph is the detailed comparison of baseline 1, intervention, and baseline 2 between the two subjects that are presented using the analysis under conditions:

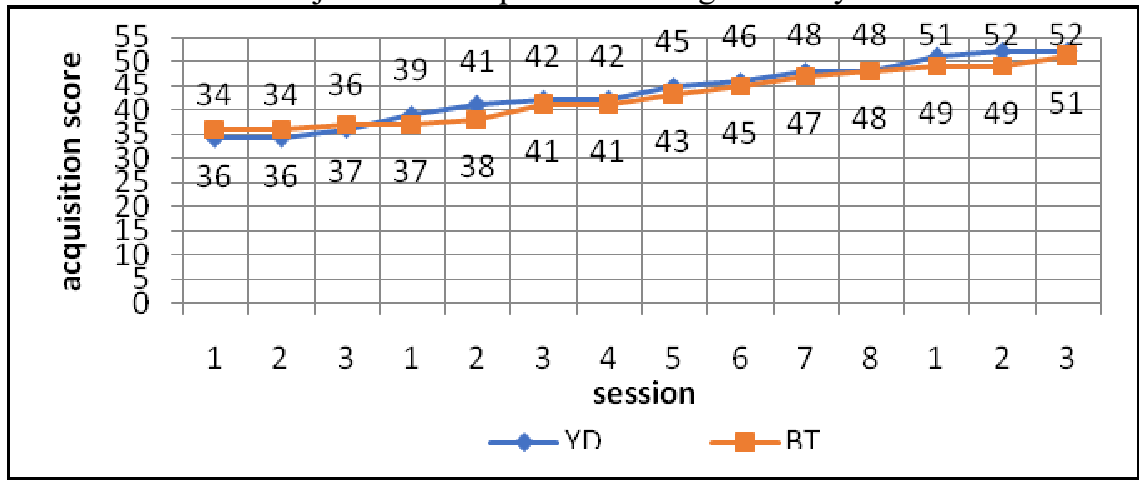

Figure 1.The Score Comparison of Reading Skill

Based on the graph above, it can be seen that the scores on both subjects were increasing in each phase. The result shown in the last phase is better than the previous phases. This proves that the provision of intervention using the Language Experience Approach can improve reading ability of dyslexic students of Surakarta X Elementary School.

Language Experience Approach can be used as a learning strategy to read. Language Experience Approach (LEA) can be described as a learning approach to reading using a basal series, but this approach cannot be combined with the other approaches. LEA allows the students to express their thoughts and experiences verbally. The ideas expressed by the students then can be written by the teachers or the students themselves. The story is then being re-read by him/her or the other students as the progress of the program. This approach can be used to develop student's word recognition skills. Phonetic and structural analysis skills are given during the observation of students' readiness to learn the lesson [2]. This approach can improve the reading ability of dyslexic subjects according to the needs and abilities of students. This is important for dyslexic children who have difficulties in reading which make it difficult for them to understand the lessons. Derek Wood, et al [21] divides the characters of dyslexic children as follows: a) Reading very slowly and unconvinced by what they were saying; b) Using their fingers to follow their eye-gazes that goes from one text to the next; c) Skipping some syllables, phrases or even lines in the text; d) Adding words or phrases that do not exist 
in the text; e) Flipping through the letters or syllables by adding other letters; f) Mispronouncing the words with other words, even if the replaced word has no significant meaning in the text; g) Making their own words that have no meaning; and h) Ignoring the punctuation. Based on those characteristics, it indicates that dyslexic children need to learn reading skills to support communication and learning process in their daily activities.

Reading skill holds an essential role. Shafi'i states that reading helps a person to understand the words expressed by others. In addition, reading can also help a person to understand the various events that happen quickly in other places. For instance, the events that occur in a particular region can be known by reading books, newspapers, magazines, and the internet [23].

Dyslexic children are required to have a good reading ability so they can find out various events in everyday life through reading books, newspapers, etc. The use of the Language Experience Approach can facilitate the students with dyslexia to improve their reading ability. The intervention given to dyslexic subjects compared to baseline 1 and baseline 2 shows the improvement in reading ability. Further, this approach provides stimulation to dyslexic children to express their feelings and thoughts. In addition, this approach fosters dyslexia children's learning motivation because of the fun learning process. In the process of research, students tend to be passionate in reading the provided text.

The same idea of the success of the use of the Language Experience Approach has also been stated in the research conducted by [13]. Rahayu states that the implementation of the Language Experience Approach is successfully increasing the motivation of learning and reading ability of the learners. Further, in her research, it is shown that $86,67 \%$ of her data show a positive effect in the learning process using the Language Experience Approach.

Another study conducted by [10] shows that the use of Language Experience Approach (LEA) improves the reading ability. It can be shown on the result of the assessment that was conducted for dyslexia students at the baseline (A) ranges from $60 \%$ to $68 \%$ and at intervention (B) increases to $86 \%$ to $92 \%$.

Furthermore, [22] has also conducted the same research. The results show that the implementation of LEA strategy can improve the ability to write simple essay for the third grade students of Tanjungrejo 2 Elementary School in Malang. Rohmawati suggests the teachers to apply LEA strategy, because the students will be more interested during the process of learning. This strategy allows the students to write their activities with pleasure. The students can write what they feel, think and then read their story, so that learning will be more meaningful for them.

[20] on her research also states that the implementation of LEA strategy can improve the ability of writing simple descriptive text of second grade students of Purwantoro 2 Elementary School in Malang. The students were required to describe the characteristics of animals in written language. The research is conducted in the hope that the teacher is expected to apply LEA system for subjects. The researcher, further hopes that the system can improve the ability to write descriptive text and follow the learning process well.

\section{CONCLUSION}

Based on the results of the research, it can be concluded that the use of language experience approach can effectively improve reading ability of second grade dyslexic students of Surakarta X Elementary School. Thus, this approach can be practically applied in the learning process of reading for second grade dyslexic students of Surakarta X Elementary School in particular, or for the other students who have the similar characteristics in general. 


\section{REFERENCES}

[1] M.J.Snowling, H.M. Nash, D.C. Gooch, M.E. Hayiou-Thomas, \& C. Hulme, "Developmental Outcomes for Children at High Risk of Dyslexia and Children With Developmental Language Disorder," Child Development, 2019.

[2] G.F. Eden, O.A. Olulade, T.M. Evans, A.J. Krafnick, \& D.R. Alkire, "Chapter 65 Developmental Dyslexia," Neurobiology of Language, pp. 815-826, 2016.

[3] G. Kome, "The Prevention, Diagnosis, and Treatment of Dyslexia," Deutsches Ärzteblatt International, vol. 107, no. 41, pp. 718-727, 2010.

[4] H.W. Catts\& Y. Petscher, "Early Identification of Dyslexia: Current Advancements and Future Directions," Perspectives on Language and Literacy, vol. 44, no. 3, pp. 33-36, 2018.

[5] J. Waterfield, "Dyslexia: Implications for Learning, Teaching and Support," Journal homepage, vol. 6, no. 1, pp. 22-24, 2015.

[6] O.A. Arisma, "Peningkatan Minat dan Kemampuan Membaca Melalui Penerapan Program Jam Baca Sekolah di Kelas VII SMP Negeri 1 Puri,"Universitas Negeri Malang 2012.

[7] C.A. Courted, J.P. Bakken, "Chapter 4 History of learning disabilities," History of Special Education, pp. 61-87, 2015.

[8] S. E. Curran, "Using The Language Experience Approach As A Part Of Differentiated Literacy Instruction," 2007.

[9] S. Elly, "Meningkatkan Kemampuan Membaca Kata Melalui Metode Fonetis Bagi Anak Tunagrahita Sedang," E-Jupekhu, vol. 1, no. 2, p. 164, 2013.

[10] O. Hidayah, "Pengaruh Language Experience Approach (LEA) pada Kemampuan Membaca Anak Lamban Belajar Kelas V di MI Bahrul Ulum Kota Batu,"Universitas Negeri Malang 2014.

[11] D.D. Nessel, \&C.N. Dixon, Using the Language Experience Approach with English Language Learners Strategies for Enganging Students Developing Literacy, United States of America: Corwin Press, 2008.

[12] Parwoto, Strategi Pembelajaran Anak Berkebutuhan, Jakarta: DEPDIKNAS, 2007.

[13] D. S. Rahayu, "The Use of Language Experience Approach in Teaching Reading for Young Learners," Journal of English and Education, vol. 1, no. 1, pp. 43-51, 2013.

[14] D. Ravid, \& R. Schiff, "Different Perspectives on the Interface of Dyslexia and Language: Introduction to the Special LLD Issue on Dyslexia and Language," Journal of Learning Disabilities, vol. 46, no. 3, pp. 195-199, 2012.

[15] J. Santrock, Psikologi Pendidikan, Jakarta: Kencana, 2013.

[16] M. Surya, Strategi Kognitif dalam Proses Pembelajaran, Bandung: Alfabeta, 2015.

[17] M. Soriano, \& A. Miranda, "Developmental dyslexia in a transparent orthography: A study of Spanish dyslexic children," Literacy and Learning, pp. 95-114, 2915.

[18] H. G. Tarigan, Membaca Sebagai Suatu Keterampilan Berbahasa, Bandung: Angkasa, 2008.

[19] D. N. Desiningrum, Psikologi Anak Berkebutuhan Khusus, Yogyakarta: Psikosain, 2016.

[20] A. Y. Kurniasih, "Peningkatan Kemampuan Menulis Deskripsi dengan Menerapkan Strategi Language Experience Approach (LEA) Pada Siswa Kelas II SDN Purwantoro 2 
Kota Malang," 2011.

[21] Loeziana, "Urgensi Mengenal Ciri Disleksia," Jurnal Ar-Raniry, vol. 3, no. 2, 2017.

[22] A. Rohmawati, "Penerapan Strategi Language Experience Approach (LEA) untuk Meningkatkan Kemampuan Menulis Karangan Sederhana di Kelas III SDN Tanjungrejo 2 Kota Malang," 2011.

[23] S. Somadayo, Strategi dan Teknik Pembelajaran Membaca, Yogyakarta: Graha Ilmu, 2011.

[24] J. Sunanto, Pengantar Penelitian dengan Subjek Tunggal, Japan: University of Tsukuba, 2005. 